\title{
Optimalisasi Fungsi Inspektorat dalam Pengawasan Keuangan Daerah di Kabupaten Kepulauan Talaud
}

\author{
ANGELA MULYANI MATEI ${ }^{1}$, HERMAN KARAMOY ${ }^{2}$, LINDA LAMBEY ${ }^{3}$ \\ ${ }^{1,2,3}$ Program Magister Akutansi, Fakultas Ekonomi dan Bisnis Universitas Sam Ratulangi \\ email : matei.angela@yahoo.com ${ }^{1}$, hkaramoy@yahoo.com ${ }^{2}$, lindalambey@yahoo.com ${ }^{3}$
}

\begin{abstract}
The function of supervision by Inspectorate is crucial to ensure the management of local government is running effectively and efficiently. As the internal supervisor institution, Inspectorate should be able to optimize its functions based on The Rule of Minister of Home Affairs Number $64 / 2007$ to create the good governance and clean government. This study is aimed to (1) determine the optimilising the function of Inspectorate in Talaud Island Municipality; (2) analyse the obstacles in optimilising the function of Inspectorate in Talaud Island Municipality; (3) analyse the strategies to optimize the function of Inspectorate in supervising local finance. This study is an exploratory qualitative research. Data were collected by in-depth interviews, observation, and study documentation from primary data and secondary data. The results show the function of Inspectorate in supervising local finance in Talaud Island Municipality is not optimal yet. It is, thus, strategies are required to overcome the obstacles in supervision of local finance by Inspectorate of Talaud Island Municipality. Strategies consist of to: (1) increase the quantitiy of inspector/audit staff; (2) increase of auditor competencies; (3) increase the allocation of supervision budget; (4) increase of facility supervision; (5) optimize the rule of internal auditor as consultant and catalyst; (6) punishment to local work unit (SKPD) staff who are not committed to conduct supervision; and (7) joint commitment of local government in supervision field.
\end{abstract}

Keywords: $\quad$ supervision, optimilising, local finance, the rule of minister of home affairs number $64 / 2007$

Abstrak. Fungsi Pengawasan Inspektorat sangat penting dalam menjamin penyelenggaraan pemerintahan daerah yang efektif dan efisien. Inspektorat sebagai lembaga pengawas internal pemerintah daerah harus mampu melaksanakan fungsinya berdasarkan Permendagri No. 64 Tahun 2007 secara optimal untuk mewujudkan tata kelola pemerintahan yang baik dan bersih. Penelitian ini bertujuan untuk : (1) mengetahui apakah fungsi Inspektorat Kabupaten Kepulauan Talaud sudah optimal; (2) menganalisis kendala-kendala yang dihadapi Inspektorat Kabupaten Kepulauan Talaud dalam optimalisasi fungsi pengawasan keuangan daerah; (3) menganalisis upaya atau strategi Inspektorat Kabupaten Kepulauan Talaud dalam mengoptimalkan fungsi pengawasan keuangan daerah. Penelitian ini menggunakan jenis penelitian kualitatif dengan pendekatan eksploratori. Pengumpulan data dilakukan melalui wawancara, observasi dan studi dokumentasi yang bersumber dari data primer dan data sekunder. Hasil penelitian ini menunjukkan fungsi Inspektorat dalam pengawasan keuangan daerah di Kabupaten Kepulauan Talaud belum optimal, sehingga dibutuhkan strategi untuk mengatasi kendala-kendala dalam pelaksanaan fungsi pengawasan yakni (1) penambahan tenaga pengawas; (2) meningkatkan kompetensi APIP; (3) meningkatkan alokasi anggaran pengawasan; (4) penambahan fasilitas pengawasan; (5) mengoptimalkan peran APIP sebagai konsultan dan katalis; (6) pemberian sanksi tegas bagi SKPD yang lalai atau kurang berkomitmen terhadap pelaksanaan pengawasan; dan (7) adanya komitmen bersama pemerintah daerah dalam bidang pengawasan.

Kata kunci: pengawasan, optimalisasi, keuangan daerah, Permendagri No. 64 Tahun 2007 


\section{Pendahuluan}

Perubahan paradigma penyelenggara-an pemerintahan daerah dari pola sentralisasi menjadi pola yang terdesentralisasi (otonomi daerah), membawa konsekuensi terhadap makin besarnya penyerahan wewenang dari pemerintah pusat kepada pemerintah daerah disatu sisi, dan disisi lain pemerintah daerah memiliki kewenangan yang besar untuk mengatur dan mengurus rumah tangganya sendiri secara otonom. Otonomi daerah dengan asas desentralisasi memberi kewenangan dan kesempatan yang luas kepada pemerintah daerah untuk menyelenggarakan pemerintahan secara bertanggung jawab dalam mewujudkan kesejahteraan masyarakat di daerah.

Bagir Manan (2000) menyatakan, otonomi yang bertanggung jawab adalah otonomi yang dalam penyelenggaraannya harus benar-benar sejalan dengan tujuan pemberian otonomi yang pada dasarnya untuk memberdayakan daerah, guna meningkatkan kesejahteraan rakyat. Oleh karena itu, pemberlakuan otonomi daerah sebagai bentuk pembagian kewenangan dari pemerintah pusat kepada pemerintah daerah, memberikan konsekuensi bagi tumbuh kembangnya kreatifitas daerah dalam mengatur dan mengelola potensi daerah bersama peran aktif masyarakat, sehingga dapat meningkatkan taraf pembangunan daerah untuk kesejahteraan masyarakatnya.

Kewenangan yang luas membutuhkan pengawasan yang optimal, karena tanpa pengawasan terbuka peluang terjadinya penyimpangan dan penyalahgunaan kewenangan, sehingga akan mengakibatkan kerugian keuangan negara, dan tidak terwujudnya kesejahteraan masyarakat. Optimalisasi pengawasan atas penyelengga-raan pemerintahan daerah selain untuk mewujudkan cita-cita otonomi daerah dalam meningkatkan kesejahteraan masyarakat, juga untuk mencegah agar tidak terjadi penyimpangan dan penyalahgunaan wewe-nang. Lord Acton dalam Tri Widodo (2008) menyatakan, bahwa manusia yang mempunyai kekuasaaan cenderung untuk menyalahgunakan kekuasaan itu, tetapi manusia yang mempunyai kekuasaan tak terbatas pasti akan menyalahgunakannya (power tends to corrupt, but absolute power corrupt absolutely).

Pengawasan atas penyelenggaraan pemerintahan daerah dilakukan oleh Inspektorat Provinsi dan Inspektorat Kabupaten/Kota. Pengawasan atas penyelenggaraan pemerintahan daerah merupakan amanat dari ketentuan Pasal 218 UU No. 32 Tahun 2004 tentang Pemerintahan Daerah, yang menyatakan: (1) Pengawasan atas penyelenggaraan pemerintahan daerah dilaksanakan oleh Pemerintah yang meliputi: a. Pengawasan atas pelaksanaan urusan pemerintahan di daerah; $b$. Pengawasan terhadap peraturan daerah dan peraturan kepala daerah. (2) Pengawasan sebagaimana dimaksud pada ayat (1) huruf a dilaksanakan oleh Aparat Pengawas Intern Pemerintah sesuai peraturan perundangundangan.

Pengawasan penyelenggaraan peme-rintahan daerah, secara lebih teknis dilaksanakan berdasarkan Permendagri No. 23 Tahun 2007 tentang Pedoman Tata Cara Pengawasan Atas Penyelenggaraan Pemerintahan Daerah. Pengawasan atas penyelenggaraan pemerintahan daerah adalah proses kegiatan yang ditujukan untuk menjamin agar pemerintah berjalan secara efisien dan efektif sesuai dengan rencana dan ketentuan peraturan perundangundangan. Artinya pengawasan sebagai salah satu upaya untuk membangun pemerintahan yang baik, bersih, dan berwibawa.

Pengawasan internal tidak hanya dilakukan pada saat akhir proses manajemen saja, tetapi berada pada setiap tingkatan proses manajemen. Pergeseran peran pengawasan internal yang telah meluas dari sekedar watch dog (menemukan penyimpangan) ke posisi yang lebih luas, yaitu sebagai konsultan dan katalis yang berorientasi pada efektivitas pencapaian misi dan tujuan organisasi, mendorong pelaksanaan pengawasan ke arah pemberian nilai tambah yang optimal. 
Kabupaten Kepulauan Talaud berdasarkan UU No. 8 Tahun 2002 Tanggal 10 April 2002, ditetapkan sebagai daerah otonomi yang baru. Laporan Hasil Pemeriksaan Badan Pemeriksa Keuangan Republik Indonesia Perwakilan Sulawesi Utara atas LKPD Kabupaten Kepulauan Talaud sejak tahun 2006 sampai dengan 2013 selalu menghasilkan opini Tidak Wajar (TW) dan Disclaimer. Peningkatan opini mulai terlihat pada tahun 2014 sampai dengan tahun 2015 menjadi Wajar Dengan Pengecualian (WDP). Hal ini antara lain disebabkan oleh permasalahan yang berulang diantaranya mengenai pengelolaan belanja modal, pengelolaan belanja barang dan jasa, pengelolaan belanja bantuan dan hibah, keterlambatan penyelesaian pekerjaan, dan pengelolaan aset tetap. Permasalahan tersebut mengakibatkan kerugian negara bahkan tidak sedikit Aparat Sipil Negera (ASN) pada Pemerintah Daerah Kabupaten Kepulauan Talaud harus berhadapan dengan kasus hukum bahkan berujung pada tuntutan pidana.

Inspektorat Kabupaten Kepulauan Talaud sebagai Lembaga Pengawas Internal Pemerintah Daerah Kabupaten Kepulauan Talaud, terbentuk berdasarkan Perda No. 06 Tahun 2008 tanggal 23 Juni 2008 tentang Organisasi dan Tata Kerja Inspektorat, Lembaga Teknis Daerah, Satuan Polisi Pamong Praja Kabupaten Kepulauan Talaud. Sebagaimana telah diatur dalam Permendagri No. 64 Tahun 2007, Inspektorat Daerah mempunyai tugas melakukan pengawasan terhadap pelaksanaan urusan pemerintahan di daerah kabupaten/kota, pelaksanaan pembinaan atas penyelengga-raan pemerintahan desa dan pelaksanaan urusan pemerintahan desa, serta menyelenggarakan fungsi: (a) perencanaan program pengawasan; (b) perumusan kebijakan dan fasilitasi pengawasan; dan (c) pemeriksaan, pengusutan, pengujian dan penilaian tugas pengawasan.

Tujuan penelitian ini untuk : (1) mengetahui apakah fungsi Inspektorat sebagai Lembaga Pengawas Internal Pemerintah Daerah Kabupaten Kepulauan Talaud sudah optimal; (2) menganalisis kendala-kendala yang dihadapi Inspektorat Kabupaten Kepulauan Talaud dalam optimalisasi fungsi pengawasan keuangan daerah; (3) menganalisis upaya atau strategi Inspektorat Kabupaten Kepulauan Talaud dalam mengoptimalkan fungsi pengawasan keuangan daerah.

\section{Model Analisis}

Model analisis pada penelitian ini dimulai dengan telaah paradigma melalui kajian isuisu empirik tentang pentingnya fungsi pengawasan dalam suatu pemerintahan daerah, kemudian menentukan topik penelitian yaitu pengawasan keuangan daerah dengan semua elemen didalamnya. Langkah berikut adalah fokus penelitian tentang optimalisasi fungsi Inspektorat dalam pengawasan keuangan daerah yang diukur dengan implementasi 3 (tiga) fungsi Inspektorat Daerah yang diatur dalam Permendagri No. 64 Tahun 2007 tentang Pedoman Teknis Organisasi dan Tata Kerja Inspektorat Provinsi dan Kabupaten/Kota. Selanjutnya adalah tahapan pengumpulan data, pengolahan/analisis data, pengujian keabsahan data, dan penyusunan hasil penelitian.

\section{Metode Penelitian}

Penelitian ini menggunakan metode penelitian kualitatif dengan pendekatan eksploratori (exploratory approach). Dengan metode ini peneliti ingin menggali informasi secara mendalam, serta hendak menggam-barkan keadaan yang sebenarnya tentang optimalisasi fungsi Inspektorat dalam pengawasan keuangan daerah di Kabupaten Kepulauan Talaud dan mengungkap berbagai permasalahan yang ditemukan oleh Aparat Pengawasan Intern Pemerintah (APIP).

Teknik pengumpulan data yang digunakan dalam penelitian ini adalah melalui wawancara mendalam (in-depth interview), observasi/pengamatan, dan studi dokumentasi. 
Selanjutnya, uji keabsahan data dalam penelitian ini meliputi triangulasi peneliti, triangulasi metode, triangulasi teori, dan triangulasi sumber data.

Dalam penelitian ini, metode analisis data yang digunakan adalah content analysis (analisis isi), yakni metode penelitian yang bersifat pembahasan mendalam terhadap isi suatu informasi tertulis ataupun tercetak. Content analysis digunakan untuk menganalisis data transcription (transkrip data) yang diolah dari hasil wawancara. Langkah-langkah dalam melakukan analisis isi menurut Senra, Oliveira, Leal, \& Vieira (2011:182) dalam Lambey (2015:93) adalah membaca transkrip wawancara sekurang-kurangnya dua kali, menganalisis setiap baris kalimat pada transkrip untuk mendapatkan makna umum maupun spesifik, dan struktur, mengidentifikasi dan memberi lebel/kode pada makna khusus dari setiap narasi, mengelompokkan kode-kode yang membentuk tema yang sama, menganalisis dan meninjau kembali setiap kategori tema dan mengelompokkan kembali dalam kategori tema yang sesuai dengan pernyataan langsung para Informan.

Tahap berikutnya dari analisis data kaulitatif yang digunakan dalam penelitian ini adalah teknik analisis Model Milles dan Huberman. Aktivitas analisis data Miles dan Huberman dalam Satori dan Komariah (2013) terdiri atas: data reduction, data display dan conclusion drawing/verification yang dilakukan secara interaktif dan berlangsung secara terus menerus sampai tuntas, sehingga datanya mencapai jenuh.

\section{Analisis dan Pembahasan}

Data hasil penelitian ini dikumpulkan dengan cara melakukan wawancara mendalam dengan metode semi terstruktur terhadap 11 (sebelas) informan yang dipilih menggunakan teknik purposive sampling, sambil melakukan observasi terhadap kegiatan atau aktivitas sehari-hari di Inspektorat Kabupaten Kepulauan Talaud, kemudian melakukan studi dokumentasi atau membandingkan hasil wawancara dengan dokumen-dokumen pengawasan, peraturan, dan teori-teori yang relevan.

\section{Peran Inspektorat Kabupaten Kepulauan Talaud dalam Pengawasan Keuangan Daerah}

Peran pengendalian dan pengawasan sangat penting untuk mencapai keberhasilan dan kemajuan organisasi. Inspektorat Daerah sebagai bagian dari pemerintahan, menjalankan perannya sebagai fungsi pengawasan yang menjamin akuntabilitas penyelenggaraan pemerintahan. Untuk lebih meningkatkan pelayanan kepada pemerintah daerah, Inspektorat juga diminta memainkan perannya dalam pengawasan dan pengendalian mutu pelayanan kepada publik atau masyarakat, khususnya yang berada di lingkungan pemerintahan daerah.

Dalam menjalankan perannya sebagai pengawas internal pemerintah daerah, Inspektorat Kabupaten Kepulauan Talaud bertujuan untuk memberikan keyakinan yang memadai atas penyelenggaraan pemerintahan untuk mewujudkan good governance dan clean government. Dengan kata lain, pengawasan Inspektorat bertujuan untuk menjamin kualitas (quality assurance) penyelengaaraan pemerintahan yang efektif dan efisien sesuai dengan perencanaan dan peraturan perundang-undangan yang ada.

Untuk menjamin pemerintahan daerah berjalan secara efisien dan efektif, Inspektorat Kabupaten Kepulauan Talaud melaksanakan pengawasan yang bersifat preventif, yaitu dengan memberikan peringatan dini dan meningkatkan efektifitas manajemen risiko dalam penyelenggaraan pemerintahan. Sehingga terjadi pergeseran peran Inspektorat dalam pengawasan, yakni watch dog yang hanya mencari-cari kesalahan di akhir kegiatan, saat ini pengawasan sudah dilakukan sejak tahap awal melalui identifikasi risiko-risiko pada setiap SKPD. Sehingga dapat mendeteksi secara dini penyimpangan-penyimpangan dalam pengelolaan keuangan daerah dan dapat mengurangi potensi temuan. Selain melaksanakan pengawasan yang bersifat preventif, Inspektorat Kabupaten Kepulauan Talaud juga berperan 
sebagai mitra kerja SKPD dalam pengelolaan keuangan daerah dengan memberikan pembinaan dan konsultasi bagi. Inspektorat Kabupaten Kepulauan Talaud juga menjalankan perannya dalam membantu tugas Bupati menyerap aspirasi dan pengaduan masyarakat terkait penyelenggaraan pemerintahan.

Menurut Horton dan Hunt (1993) peran adalah perilaku yang diharapkan dari seseorang yang memiliki suatu status. Berbagai peran yang yang tergabung dan terkait pada satu status ini disebut perangkat peran (role set). Teori peran menggambarkan interaksi sosial dalam terminologi aktor-aktor yang bermain sesuai dengan perannya masing-masing. Seseorang yang mempunyai peran tertentu diharapkan agar berperilaku sesuai dengan perannya tersebut. Pemerintah dan masyarakat masuk dalam satu perangkat peran (role set) pemerintah sebagai pelayan publik yaitu bertanggung jawab untuk mewujudkan kesejahteraan rakyatnya. Inspektorat Kabupaten Kepualaun Talaud sebagai bagian dari pemerintah daerah, menjalankan perannya dalam fungsi pengawasan yang menjamin akuntabilitas penyelenggaraan pemerintahan. Inspektorat perlu memainkan perannya dalam pengawasan dan pengendalian mutu pelayanan kepada publik, sehingga tujuan otonomi daerah dalam menyejahterakan masyarakat dapat tercapai.

\section{Implementasi Fungsi Inspektorat dalam Pengawasan Keuangan Daerah di Kabupaten Kepulauan Talaud}

Penyelenggaraan pengawasan merupa-kan implementasi kebijakan di bidang pengawasan. Implementasi kebijakan merupakan faktor yang paling penting bagi keberhasilan sebuah kebijakan, tanpa diimplementasikan kebijakan publik hanya akan menjadi dokumentasi belaka. Pemerintah telah menetapkan Permendagri No. 64 Tahun 2007, sebagai salah satu kebijakan yang memuat fungsi Inspektorat dalam pengawasan penyelenggaraan pemerintahan daerah yang harus diimplementasikan oleh setiap lembaga pengawasan internal pemerintah daerah.

\section{Perencanaan Program Pengawasan}

Dalam melaksanakan fungsi Perencanaan Program Pengawasan, Inspektorat Kabupaten Kepulauan Talaud mengimplementasikannya dengan menyu-sun Program Kerja Pengawasan Tahunan (PKPT) yang terintegrasi dengan dokumen perencanaan daerah mulai dari RPJMD, RKPD, dan RENSTRA Inspektorat selaku pengawas internal pemerintah daerah.

\section{Perumusan Kebijakan dan Fasilitasi Pengawasan}

Inspektorat Kabupaten Kepulauan Talaud melaksanakan fungsi Perumusan Kebijakan dan Fasilitasi Pengawasan dengan membuat kebijakan pengawasan yang berpedoman pada kebijakan pengawasan pemerintah pusat dan provinsi yang disesuaikan dengan karakteristik daerah. Hal ini untuk menghindari tumpang-tindih dalam pelaksanaan fungsi pengawasan dan sinkronisasi program pengawasan mulai dari pemerintah pusat, pemerintah provinsi, sampai pada pemerintah daerah. Perumusan kebijakan pengawasan juga mengacu pada hasil evaluasi pada tahun sebelumnya, sehingga bisa disusun kebijakan pengawasan yang sesuai dengan kebutuhan.

\section{Pemeriksaan, Pengusutan, Pengujian dan Penilaian Tugas Pengawasan}

Fungsi Pemeriksaan, Pengusutan, Pengujian dan Penilaian Tugas Pengawasan dilaksanakan oleh Inspektorat Kabupaten Kepulauan Talaud melalui kegiatan-kegiatan pengawasan seperti pemeriksaan keuangan baik pemeriksaan reguler maupun tematik, monitoring dan evaluasi pelaksanaan kegiatan maupun pekerjaan, reviu yang dimulai dari RKA, LAKIP, dan LKPD, serta melakukan tindak lanjut temuan BPK. 
Setiap produk kebijakan harus dikaji dan dinilai keberhasilannya melalui implementasi kebijakan tersebut secara aktual. Keberhasilan implementasi kebijakan ditentukan oleh banyak faktor, dan masing-masing faktor tersebut saling berhubungan satu sama lain. George C. Edward III (1980:9) dikutip oleh Tahir (2014), menyatakan bahwa implementasi kebijakan publik dipengaruhi oleh empat faktor yakni komunikasi, sumber daya, disposisi atau prilaku, dan struktur birokrasi.

Hasil penelitian menunjukkan pelaksanaan implementasi kebijakan pengawasan dalam hal ini Permendagri Nomor 64 Tahun 2007 oleh Inspektorat Kabupaten Kepulauan Talaud belum optimal. Hal ini disebabkan oleh masih adanya kendala-kendala dalam pelaksanaan pengawasan baik kendala internal maupun eksternal.

\section{Kendala Internal}

\section{Sumber Daya Manusia}

Keterbatasan jumlah sumber daya pemeriksa yang tidak sebanding dengan banyaknya objek pemeriksaan Inspektorat Kabupaten Kepulauan Talaud menjadi salah satu kendala dalam pelaksanaan fungsi pengawasan keuangan daerah. Selain itu jumlah auditor yang dimiliki Inspektorat Kabupaten Kepulauan Talaud belum memadai. Saat ini Inspektorat baru memiliki 9 auditor yang sudah mengikuti diklat dan memiliki sertifikat. Hal ini tentu menjadi kendala dalam pengawasan keuangan daerah mengingat pentingnya kompetensi dan kualifikasi seorang tenaga pemeriksa.

Herdi Setiawan dan Tri Sukirno Putro (2013) dalam penelitiannya mengemukakan salah satu faktor yang mempengaruhi tugas pokok dan fungsi Inspektorat adalah sumber daya manusia. Selanjutnya menurut Edward III (1980), salah satu faktor yang sangat mempengaruhi keberhasilan implementasi kebijakan adalah sumber daya (resources). Sumber daya adalah faktor penting untuk implementasi kebijakan agar efektif. Sumber daya manusia yang tidak memadai (jumlah dan kemampuan) berakibat tidak dapat dilaksanakannya kebijakan secara sempurna serta tidak mampu melakukan pengawasan dengan baik.

\section{Anggaran Pengawasan}

Dalam pelaksanaan fungsi pengawasan keuangan daerah, Inspektorat Kabupaten Kepulauan Talaud masih terkendala dari segi anggaran pengawasan yang belum sesuai dengan Permendagri Nomor 71 Tahun 2015 yang mewajibkan pemerintah daerah untuk mengalokasikan anggaran pengawasan Inspektorat Daerah sebesar $1 \%$ dari APBD tahun 2016. Hal ini mengakibatkan masih ada beberapa kegiatan pengawasan yang tidak terlaksana karena keterbatasan anggaran.

Menurut Luchman Sanjaya (2015) dalam penelitiannya, keterbatasan anggaran pemeriksaan merupakan salah satu kendala dalam pelaksanaan fungsi pengawasan Inspektorat. Anggaran berdasarkan fungsinya adalah alat untuk mencapai tujuan organisasi (Mulyadi, 2002:488). Dalam pelaksanaan fungsi pengawasan Inspektorat, alokasi anggaran yang memadai sangat diperlukan untuk mencapai tujuan pengawasan dalam menjamin penyelenggaraan pemerintahan daerah yang efektif dan efisien.

\section{Fasilitas Pengawasan}

Fasilitas merupakan salah satu faktor penunjang dalam pelaksanaan fungsi pengawasan. Namun dalam pelaksanaannya, fasilitas pengawasan di Inspektorat Kabupaten Kepulauan Talaud dirasa masih belum memadai, yakni dari segi sarana transportasi, karena masih banyak tenaga pengawas atau auditor yang menggunakan kendaraan pribadi dalam 
melakukan tugas pengawasan. Walaupun demikian, fasilitas penunjang lainnya seperti laptop, printer, scanner, kamera, dan alat ukur lainnya sudah cukup memadai.

Menurut J. Coyle-Shapiro, K. Hoque, I. Kessler, A. Pepper, R. Richardson dan L. Walker (2013) salah satu strategi peningkatan kinerja seorang pekerja adalah perusahaan harus menyediakan fasilitas penunjang yang dapat membantu dan mempermudah dia dalam melaksanakan tugas-tugasnya. Fasilitas adalah salah satu penunjang pelaksanaan fungsi pengawasan Inspektorat (Indarwati, 2013).

\section{Kendala Eksternal}

\section{Auditi}

Kurangnya pemahaman auditi (pihak yang diperiksa) terhadap pengelolaan keuangan daerah terlebih dalam pengelolaan dana desa sering menjadi kendala dalam pelaksanaan pemeriksaan keuangan. Hal ini tak bisa dipungkiri karena memang pengelolaan dana desa masih merupakan hal baru bagi pemerintah desa. Selain itu, masih ada auditi yang kurang kooperatif dalam pelaksanaan pemeriksaan, sehingga menyulitkan pemeriksa dalam memperoleh dokumen pemeriksaan.

Pemahaman peraturan adalah pemahaman anggota/pegawai mengenai peraturan, prosedur dan kebijakan tentang peraturan daerah (Kiranayanti, 2016). Peraturan yang dimaksud disini adalah yang berkaitan dengan pengelolaan keuangan daerah diantaranya, Permendagri Nomor 13 Tahun 2006 tentang Pedoman Pengelolaan Keuangan Daerah, dan PP No. 71 Tahun 2010 tentang Standar Akuntansi Pemerintah Berbasis Akrual. Para pengelola perlu memiliki pemahaman memadai tentang standar akuntansi pemerintah daerah agar dapat menyajikan laporan keuangan yang handal.

\section{Mutasi Pejabat Pengelola Keuangan}

Pergantian atau mutasi pejabat pengelola keuangan yang tidak pada waktunya, juga menjadi kendala dalam pelaksanaan fungsi pengawasan Inspektorat Kabupaten Kepulauan Talaud. Menurut Ikhsan, (2006:18), salah satu permasalahan pokok yang ada dalam birokrasi pemerintah adalah pengelolaan atau manajemen kepegawaian, mulai dari rekrutmen, peneta-pan formasi, perekrutan, penempatan, pengembangan hingga pensiun PNS. Mutasi atau pergantian pejabat hendaknya harus sesuai dengan peraturan kepegawaian yang ada, sehingga tidak mengganggu jalannya penyelenggaraan pemerintahan daerah.

\section{Letak Geografis}

Letak geografis Kabupaten Kepulauan Talaud yang adalah daerah kepulauan dengan medan transportasi yang sulit dan cuaca yang tidak menentu, sering menjadi kendala dalam pelaksanaan fungsi pengawasan Inspektorat Kabupaten Kepulauan Talaud. Keberhasilan suatu sistem ditunjang oleh faktor tersedianya infrastruktur yang baik (Mankiw, 2003). Begitu pula dengan sistem pengawasan di Kabupaten Kepulauan Talaud harus ditunjang dengan infrastrukur yang memadai. Kondisi jalan dan medan transportasi yang sulit dijangkau menghambat pelaksanaan pengawasan.

\section{Optimalisasi Fungsi Inspektorat dalam Pengawasan Keuangan Daerah di Kabupaten Kepulauan Talaud}

Dalam rangka optimalisasi fungsi pengawasan keuangan daerah, Inspektorat Kabupaten Kepulauan Talaud melaksanakan beberapa upaya dan strategi yang diharapkan mampu menjamin terselengga-ranya pengelolaan keuangan daerah yang efektif dan efisien, sehingga mampu mewujudkan komitmen pemerintah daerah dalam menuju peningkatan 
opini atas pengelolaan keuangan daerah atau yang lebih dikenal dengan "Talaud road to WTP 2017."

\section{Peningkatan Peran APIP}

Pergeseran peran APIP dari watch dog menjadi konsultan dan katalis menuntut APIP Inspektorat Kabupaten Kepulauan Talaud untuk lebih memaksimalkan pemberian jasa konsultasi, memberikan jaminan kualitas pada setiap tugas pengawasan dan membantu SKPD dalam proses identifikasi risiko serta menjadi mitra kerja SKPD dalam pengelolaan keuangan daerah.

Peningkatan kompetensi APIP menjadi salah satu faktor penentu dalam keberhasilan pelaksanaan fungsi pengawasan. Untuk itu APIP Inspektorat Kabupaten Kepulauan Talaud terus meningkatkan kemampuan profesionalnya melalui diklat pembentukan auditor yang sudah diikuti sebanyak 9 (sembilan) orang, dan pelatihan serta diklat teknis lainnya. Hal ini dimaksudkan untuk terus membekali para tenaga pemeriksa/auditor Inspektorat Kabupaten Kepulauan Talaud dengan perkembangan pengetahuan dan keahlian dalam bidang pengawasan sehingga dapat melaksanakan perannya dengan optimal.

Dalam menjalankan tugas dan fungsinya APIP wajib mematuhi kode etik yang diatur dalam Permenpan No. PER/04/M.PAN/03/2008. Pelaksanaan kepa-tuhan terhadap kode etik di Inspektorat Kabupaten Kepulauan Talaud sudah berjalan dengan baik dan belum ditemui masalah terkait pelanggaran kode etik. Namun yang harus menjadi perhatian adalah perlu adanya penyusunan dan penetapan Kode Etik APIP Inspektorat Kabupaten Kepulauan Talaud secara khusus.

Pengawasan Inspektorat dalam penyelenggaraan pemerintahan daerah agar dapat optimal dalam mewujudkan tata pemerintahan yang baik (good governance), maka perlu adanya penguatan peran APIP dan meningkatkan kompetensi dan profesionalisme (Indarwati, 2013). Untuk itu, peningkatan peran APIP Inspektorat Kabupaten Kepulauan Talaud sangat dibutuhkan dalam upaya optimalisasi fungsi pengawasan keuangan daerah.

\section{Pelaksanaan Pengawasan Berbasis Risiko}

Untuk mengoptimalkan fungsinya dalam memberikan keyakinan yang memadai atas penyelenggaraan pemerintah-an, serta memberikan peringatan dini dan meningkatkan manajemen risiko dalam penyelenggaraan pemerintahan, Inspektorat Kabupaten Kepulauan Talaud mulai melaksanakan implementasi kebijakan pengawasan yang berbasis risiko, yakni melalui : (1) penyusunan PKPT yang berbasis risiko sehingga pelaksanaan pemeriksaan keuangan tidak lagi bersifat reguler tapi sudah bersifat tematik yaitu berdasarkan kebutuhan auditi dan identifikasi risiko dalam pengelolaan keuangan daerah; (2) lingkup pemeriksaan sudah dimulai dari awal, yaitu pada tahap perencanaan melalui pelaksanaan reviu dokumen perencanaan SKPD yang harus terintegrasi dengan dokumen perencanaan daerah dan sesuai dengan peraturan yang ada, kemudian pada tahap pelaksanaan, hingga pada tahap pertanggungjawaban dan pelaporan.

Manajemen risiko merupakan salah satu peran yang tidak bisa dipisahkan dari pengawasan internal. Standar auditing mengharuskan auditor memahami entitas dan lingkungannya termasuk pengendalian internalnya untuk menilai risiko salah saji yang material dalam laporan keuangan klien. Respon yang baik atas risiko-risiko ini sangat menentukan dalam mencapai audit yang bermutu (Arens, et.al, 2015:302). Inspek-torat Kabupaten Kepulauan Talaud perlu dan harus melaksanakan dan meningkatkan pengawasan yang berbasis risiko, sehingga pelaksanaan pengawasan mampu menjawab setiap kebutuhan permasalahan dalam pengelolaan keuangan daerah dan memberikan quality assurance dalam setiap pelaksanaan fungsi pengawasan. 


\section{Penguatan Sistem Pengawasan}

Inspektorat Kabupaten Kepulauan dalam menjalankan tugas dan fungsi pengawasan, terus melakukan koordinasi baik dengan pimpinan daerah, maupun dengan pihak SKPD sebagai objek pengawasan, sehingga sistem pengawasan dapat berjalan dengan baik. Adanya komitmen yang tinggi dari Pimpinan Daerah Kabupaten Kepulauan dalam pengawasan dengan memberikan kewenangan penuh kepada Inspektorat dalam pelaksanaan tugas dan fungsinya tanpa ada intervensi, sehingga independensi Inspektorat sebagai Lembaga Pengawas Internal Pemerintah Daerah tetap terjaga.

Independensi berarti sikap mental yang bebas dari pengaruh, tidak dikendalikan oleh pihak lain, tidak tergantung pada orang lain. Independensi juga berarti adanya kejujuran dalam diri auditor dalam merumuskan dan menyatakan pendapatnya (Mulyadi, 2002:26-27). Inspektorat Kabupaten Kepulauan Talaud berada di bawah dan bertanggung jawab kepada Bupati Kepulauan Talaud, memungkinkan adanya gangguan terhadap independensi Inspektorat dalam melakukan pengawasan. Akan tetapi adanya koordinasi yang baik antara pemerintah daerah dengan Inspektorat sebagai organisasi pengawas, serta komitmen pimpinan daerah dan jajarannya untuk menciptakan good governance dan clean government, maka independensi Inspektorat tetap terjaga tanpa adanya intervensi.

\section{Penutup}

Kesimpulan penelitian adalah pelaksanaan fungsi Inspektorat dalam pengawasan keuangan daerah di Kabupaten Kepulauan Talaud belum optimal. Hal ini disebabkan masih adanya kendala-kendala dalam pengawasan keuangan daerah, yakni kendala internal : (1) sumber daya manusia; (2) anggaran pengawasan; (3) fasilitas pengawasan, dan kendala eksternal : (1) auditi; (2) mutasi pejabat pengelola keuangan; (3) letak geografis. Upaya atau strategi yang dilakukan oleh Inspektorat Kabupaten Kepulauan Talaud untuk mengoptimalkan fungsi pengawasan keuangan daerah adalah dengan melakukan (1) peningkatan peran APIP; (2) pelaksanaan pengawasan berbasis risiko; (3) penguatan sistem pengawasan. Hal ini diharapkan mampu menjamin terselenggaranya pengelolaan keuangan daerah yang efektif dan efisien, dan mewujudkan kesejahteraan masyarakat sesuai dengan tujuan otonomi daerah. Selain itu optimalisasi fungsi Inspektorat dalam pengawasan keuangan daerah diharapkan mampu mewujudkan komitmen pemerintah daerah dalam meningkatkan opini atas pengelolaan keuangan daerah atau yang lebih dikenal dengan "Talaud road to WTP 2017."

Saran yang dapat diberikan dari penelitian ini : (1) perlu adanya penambahan jumlah SDM/tenaga pengawas yang sesuai dengan kebutuhan organisasi. Inspektorat perlu membuat analisis kebutuhan pegawai baik dari segi jumlah maupun kompetensi yang dibutuhkan, kemudian berkoordinasi dengan BKDD sebagai instansi yang berperan dalam rekrutmen Pegawai Negeri Sipil di daerah; (2) Inspektorat Kabupaten Kepulauan Talaud perlu memiliki prosedur rekrutmen, pengangkatan, pengembangan berkelanjutan, dan evaluasi atas pemeriksa untuk membantu organisasi pemeriksa dalam mempertahankan pemeriksa yang memiliki kompetensi yang memadai; (3) Pemerintah Daerah Kabupaten Kepulauan Talaud perlu meningkatkan alokasi anggaran pengawasan Inspektorat, sehingga dapat melaksanakan tugas dan fungsi pengawasan yang sesuai dengan kebutuhan berdasarkan identifikasi risiko dalam pengelolaan keuangan dan bukan hanya berdasarkan besarnya alokasi anggaran saja; (4) perlu adanya pengadaan atau penambahan fasilitas pengawasan, yakni kendaraan operasional seperti sepeda motor bagi para auditor dalam melakukan tugas pengawasan. Perbaikan infrastruktur jalan sebagai sarana transportasi juga perlu mendapat perhatian serius dari pemerintah sebagai salah satu faktor penunjang pelaksanaan fungsi 
pengawasan Inspektorat; (5) Inspektorat Kabupaten Kepulauan Talaud perlu meningkatkan peran APIP sebagai mitra kerja SKPD. Peran APIP yang mengalami pergeseran paradigma dari peran watch dog (sekedar mencari-cari kesalahan) harus dioptimalkan menjadi lebih fokus pada unsur pengawasan yang bersifat preventif, consultative, dan quality assurance pada program-program strategis yang mempunyai risiko tinggi terhadap penyimpangan, early warning system, pendampingan dan pembinaan terhadap SKPD. Selain itu perlu membuat dan menetapkan Kode Etik APIP Inspektorat Kabupaten Kepulauan Talaud sebagai salah satu standar dalam melaksanakan tugas audit; (6) Inspektorat Kabupaten Kepulauan Talaud perlu memberikan sanksi tegas bagi SKPD yang lalai atau kurang berkomitmen terhadap pelaksanaan pengawasan Inspektorat, baik terhadap kegiatan audit, reviu, monitoring, dan pelaksanaan tindak lanjut. Fungsi pengawasan Inspektorat harus dipandang penting oleh semua SKPD dan menjadi kebutuhan dalam pengelolaan keuangan daerah yang akuntabel, transparan, efektif dan efisien; (7) perlu adanya political will dan komitmen bersama pemerintah daerah dalam hal ini Tim BAPERJAKAT terkait pergantian atau mutasi pegawai khususnya pejabat pengelola keuangan di SKPD baik Pengguna Anggaran/Kuasa Pengguna Anggaran (PA/KPA), Pejabat Pembuat Komitmen (PPK), Pejabat Pelaksana Teknis Kegiatan (PPTK) maupun Bendahara harus mempertimbangkan penilaian kinerja dan waktu yang tepat terkait dengan pelaksanaan dan pertanggungjawaban kegiatan yang menjadi kewenangannya di SKPD.

\section{Daftar Pustaka}

Arens, Alvin A., Randal J. Elder, Mark S. Beasley. (2015). Auditing \& Jasa Assurance : Pendekatan Terintegrasi. Jilid I, Edisi Kelimabelas. Jakarta: Erlangga

Coyle-Shapiro J., K. Hoque, I. Kessler, A. Pepper, R. Richardson dan L. Walker. 2013. Human Resource Management : Undergraduate Study in Economics, Management, Finance and Social Science. University of London.

Horton, Paul B. dan Chester L. Hunt. 1993. Sosiologi. Terjemahan Aminuddin Ram dan Tita Sobari. Jakarta: Erlangga.

Ikhsan. 2006. Standar Pelayanan Publik di Daerah Jakarta : Hand Book Manajemen Pemerintahan Daerah. LAN.

Indarwati, Ch. Merry. 2013. Optimalisasi Pengawasan Inspektorat Kabupaten Magelang dalam Mewujudkan Tata Pemerintahan yang Baik (Good Governance). Halaman : http://e-journal.uajy.ac.id/id/eprint/1246. Diakses tanggal 11 September 2016.

Kiranayanti, Ida Ayu Enny. 2016. Pengaruh Sumber Daya Manusia, Sistem Pengendalian Intern, Pemahaman Basis Akrual Terhadap Kualitas Laporan Keuangan Daerah. e-Jurnal Akuntansi Universitas Udayana. ISSN: 2302-8556, Vol.16. No.2. Universitas Udayana. Bali. Lambey, Linda. 2015. Mental Models Of Employment And The Psychological Contracts Of Indonesian Academics: An Exploratory Study. Thesis: The University of Newcastle, Australia.

Manan, Bagir. 2000. Menyongsong Fajar Otonomi Daerah. Yogyakarta: Pusat Studi Hukum (PSH) Fakultas Hukum UII.

Mankiw, N. Gregory. 2003. Teori Makro Ekonomi Terjemahan. Jakarta: PT. Gramedia Pustaka Utama.

Mulyadi. 2002. Auditing. Buku Dua, Edisi Ke Enam. Jakarta: Salemba Empat.

Sanjaya, Luchman. 2015. Optimalisasi Pengawasan Pengelolaan Keuangan Daerah di Kabupaten Sidoarjo. Journal of Knowledge Management Practice (ISSN. 2338-445X). Vol. 3, No. 1, Maret 2015, Hal. 1-116. Universitas Airlangga. Surabaya.

Satori, Djam'an dan Aan Komariah. 2013. Metodologi Penelitian Kualitatif. Bandung: Alfabeta. 
Setiawan, Herdi dan Tri Sukirno Putro. 2013. Optimalisasi Fungsi Inspektorat dalam Pengawasan Keuangan Daerah. Jurnal Kebijakan Publik. Vol. 4, No. 2, Oktober 2013, Hal. 119-218. Universitas Riau. Riau.

Tahir, Arifin (2014), Kebijakan Publik \& Transparansi Penyelenggaraan Pemerin-tah Daerah. Bandung : CV. Alfabeta

Widodo, Tri. 2008. Etika dan Hukum Administrasi Publik. Jakarta: PT. Salemba. 